\title{
The effect of prophylactic vancomycin powder on infections following spinal surgeries: a systematic review
}

\author{
Vincent Dodson, BS, Neil Majmundar, MD, Vanessa Swantic, MS, and Rachid Assina, MD \\ Department of Neurosurgery, Rutgers New Jersey Medical School, Newark, New Jersey
}

OBJECTIVE The use of vancomycin powder in spine surgery for prophylaxis against surgical site infections (SSIs) is well debated in the literature, with the majority of studies demonstrating improvement and some studies demonstrating no significant reduction in infection rate. It is well known in certain populations that vancomycin powder reduces the general rate of infection, but its effects on reducing the rate of infection due to gram-negative pathogens are not well reviewed. The goal of this paper was to review studies that investigated the efficacy of vancomycin powder as a prophylactic agent against SSI and demonstrate whether the rate of infections by gram-negative pathogens is impacted.

METHODS An electronic search of the published literature was performed using PubMed and Google Scholar in accordance with the PRISMA (Preferred Reporting Items for Systematic Reviews and Meta-Analyses) guidelines. A variety of combinations of the search terms "vancomycin powder," "infection," "spine," "gram-negative," "prophylaxis," and "surgical site" was used. Inclusion criteria were studies that 1) described an experimental group that received intraoperative intrawound vancomycin powder; 2) included adequately controlled groups that did not receive intraoperative intrawound vancomycin powder; 3) included the number of patients in both the experimental and control groups who developed infection after their spine surgery; and 4) identified the pathogen-causing infection. Studies not directly related to this review's investigation were excluded from the initial screen. Among the studies that met the criteria of the initial screen, additional reasons for exclusion from the systematic review included lack of a control group, unspecified size of control groups, and inconsistent use of vancomycin powder in the experimental group.

RESULTS This systematic review includes 21 studies with control groups. Vancomycin powder significantly reduced the relative risk of developing an SSI (RR 0.55, 95\% Cl 0.45-0.67, $\mathrm{p}<0.0001)$. In addition, the use of vancomycin powder did not significantly increase the risk of infection by gram-negative pathogens (RR $1.11,95 \% \mathrm{Cl} 0.66-1.86, p=0.701)$.

CONCLUSIONS The results of this systematic review suggest that intrawound vancomycin powder is protective against SSI. It is less clear if this treatment increases the risk of gram-negative infection. Further studies are required to investigate whether rates of infection due to gram-negative pathogens are affected by the use of vancomycin powder.

https://thejns.org/doi/abs/10.3171/2018.10.FOCUS18470

KEYWORDS vancomycin powder; spine surgery; gram-negative; prophylaxis; surgical site infection; spinal fusion

$\mathrm{S}$ URGICAL site infection (SSI) remains a significant concern, both in terms of patient morbidity and cost to the healthcare system. ${ }^{8,21}$ The rate of postoperative wound infection following spine surgery in particular has been estimated to be between $2 \%$ and $13 \%{ }^{7,28,29}$ As such, decreasing the rate of infection with vancomycin powder has typically become the standard of care for instrumented spine surgeries in most institutions in the United States. Several studies have shown that the rate of infections decreases with the use of vancomycin powder, but the population that would benefit most from its use has not been clearly defined. Furthermore, the rate of infections due to gram-negative pathogens since the inception of vancomycin powder in spine surgery has not been studied.

Risk factors for developing an SSI following spinal surgery include preexisting diabetes, trauma, insufficient irrigation, history of previous spinal surgery, smoking, and obesity. ${ }^{29,40}$ As infection by gram-positive pathogens, such as Staphylococcus aureus, is common in SSI, several studies have investigated the use vancomycin powder for prophylaxis, but the results have been inconsistent. Several studies have documented significant improvement in the rate of SSI following treatment with vancomycin powder, while others did not demonstrate a significant

ABBREVIATIONS NOS = Newcastle-Ottawa Scale; $\mathrm{SSI}=$ surgical site infection . 
reduction. ${ }^{4-6,10,14-16,18,19,22-27,30-39,43}$ Furthermore, while vancomycin targets gram-positive pathogens, some studies have demonstrated that it can increase the relative risk of infection by gram-negative pathogens. As the incidence of septic shock is higher in gram-negative bacteremia than in gram-positive bacteremia, the potential that vancomycin has to select for gram-negative pathogens is of clinical significance. ${ }^{1}$ Furthermore, the structural differences between gram-negative and gram-positive bacteria make gram-negative bacteremia intrinsically more difficult to treat. ${ }^{3}$ The primary goal of this review was to study the effects of prophylactic vancomycin powder use on SSIs and to investigate whether the published data demonstrate a relative increase in the percentage of infections due to gram-negative pathogens.

\section{Methods}

An electronic search of published literature was performed using Google Scholar and PubMed in accordance with the PRISMA (Preferred Reporting Items for Systematic Reviews and Meta-Analyses) guidelines. Studies were selected to answer 2 research questions: "Does intrawound vancomycin powder decrease the risk of SSI?" and "Is the risk of infection by gram-negative pathogens greater in patients who receive intrawound vancomycin powder?" A variety of combinations of the search terms "vancomycin powder," "infection," "spine," "gram-negative," "prophylaxis," and "surgical site" were used. Inclusion criteria for the first research question were studies that 1) described an experimental group that received intraoperative intrawound vancomycin powder; 2) included adequately controlled groups that did not receive intraoperative intrawound vancomycin powder; and 3) included the number of patients in both the experimental and control groups who developed infection after their spine surgery. For the second research question, the inclusion criteria were the aforementioned 3 criteria with the addition of the following: studies that identified the pathogen-causing infection.

Studies not directly related to this review's investigation were excluded from the initial screen. Among the studies that met the criteria of the initial screen, additional reasons for exclusion from the systematic review include lack of a control group, unspecified size of control groups, and inconsistent use of vancomycin powder in the experimental group.

The authors (V.D., N.M., and V.S.) extracted the following data from the included studies: 1) the number of spine surgery patients who did not receive vancomycin powder; 2) the number of spine surgery patients who did receive vancomycin powder; 3) the number of patients in both groups who developed subsequent infection; 4) the dosage of the administered vancomycin powder; 5) the intraoperative antibiotics used in the control group; and 6) the causative pathogen of the SSIs, if available. We identified and graded the type of each study. Retrospective/prospective cohort studies were scaled using the Newcastle-Ottawa Quality (NOS) for quality assessment, ${ }^{40}$ and randomized controlled trials were assessed using the Jadad scale. ${ }^{20}$

For each of the included studies, the relative risk of infection was calculated with $95 \%$ confidence intervals. For the first research question, the relative risk of developing infection in the treatment group compared with the control group was calculated. For the second research question, the relative risk of developing infection by gram-negative pathogens in the treatment group compared with the control group was calculated.

\section{Results}

Our initial search from PubMed and Google Scholar yielded a total of 1067 studies (225 from PubMed and 842 from Google Scholar). After duplicates were removed, 617 studies remained. Of the 617 studies, 24 studies were identified that were directly related to our research questions. Three of the 24 studies were subsequently excluded because of their study design. The PRISMA flow diagram is included as Fig. 1.

Of the 21 included studies, 19 were retrospective/prospective cohort studies, while 2 were randomized controlled trials. Neither of the randomized controlled trials was blinded, so both were scored a 3 of 5 on the Jadad scale. The quality of the cohort studies as scaled by the NOS and of the randomized controlled trials as scaled by the Jadad score are shown in Table 1.

In the 21 controlled studies included for analysis, 11,607 spine surgery patients did not receive vancomycin powder. Of these patients, 330 developed SSIs, giving an infection rate of $2.8 \%$. The remaining patients $(n=8075)$ received some amount of vancomycin powder. The dosage of vancomycin powder ranged from 0.5 to $2 \mathrm{~g}$. Of these patients, 126 developed an SSI, giving an infection rate of $1.6 \%$. The relative risk was calculated for each study. The cumulative relative risk was determined to be 0.55 (95\% CI $0.45-0.67, \mathrm{p}<0.0001)$. The number needed to treat was 78 patients. Results for this initial analysis are shown in Table 1 , and the respective forest plot is shown in Fig. 2.

Of the 21 studies included for analysis, 10 studies included information about the causative pathogens in the SSI cases. Infection by a gram-negative pathogen was found in 35 of of 8271 patients who were not treated with vancomycin powder for an infection rate of $0.42 \%$. Within the vancomycin treatment group, infection by a gramnegative pathogen was found in 24 of 5123 patients for an infection rate of $0.47 \%$. The cumulative relative risk was determined to be 1.11 (95\% CI 0.66-1.86, p = 0.701). Results for this secondary analysis are shown in Table 2, and the respective forest plot is shown in Fig. 3.

\section{Discussion}

Several studies have shown that vancomycin powder reduces the risk of postoperative spinal infection, thereby reducing the overall cost of care. SSI is a significant burden on the healthcare system. It is estimated that SSIs cost the United States healthcare system up to $\$ 10$ billion per year and up to $\$ 100,000$ in additional costs per patient..$^{13,17}$ Even a mild reduction in this cost can result in significant savings across the healthcare system. While vancomycin powder is effective in treating infections due to gram-positive pathogens, such as methicillin-resistant Staphylococcus aureus, its clinical utility in treating infections due to gram-negative pathogens is quite limited. 


\section{PRISMA Flow Diagram}

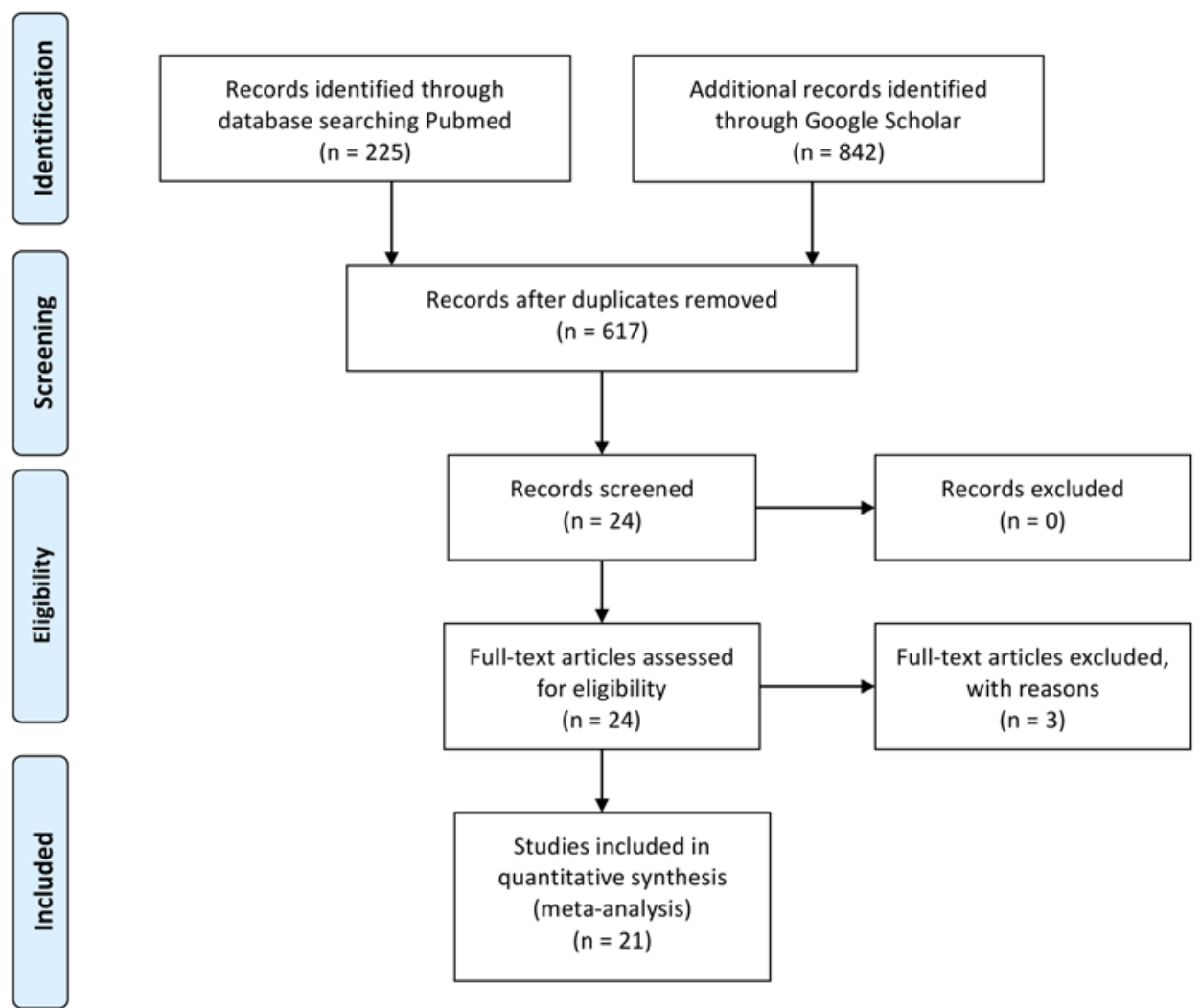

FIG. 1. PRISMA flow diagram. Data added to the PRISMA template (from Moher D, Liberati A, Tetzlaff J, Altman DG, The PRISMA Group (2009). Preferred Reporting Items for Systematic Reviews and Meta-Analyses: The PRISMA Statement. PLoS Med 6(7): e1000097) under the terms of the Creative Commons Attribution License.

\section{Vancomycin Reduces SSIs}

A study of thoracolumbar fusion surgery patients by Sweet et al. was the first to demonstrate that vancomycin powder significantly reduces the rate of SSI. ${ }^{34}$ Since then, several more studies have demonstrated a similar effect for a variety of spine surgeries. The largest such study was conducted by Schroeder et al., who found that for several types of spinal surgery, vancomycin powder significantly reduced the rate of postoperative deep wound infections. ${ }^{30}$ The study by Horii et al. was one of the few that failed to demonstrate the prophylactic benefit of vancomycin powder, most likely because their vancomycin treatment group was in many aspects sicker than the control group. Their vancomycin treatment group had a significantly higher rates of diabetes mellitus, history of spinal surgery, hemodialysis, and immunosuppressant use, all of which increase the likelihood of infection..$^{19}$

\section{SSI Secondary to Gram-Negative Pathogen}

While 21 studies were included in the analysis for this review, some studies were excluded because of their limited results. A study by Ghobrial et al. retrospectively reviewed patients with SSI. ${ }^{11}$ The authors studied all patients who experienced an SSI and investigated whether or not those patients received vancomycin powder intraoperatively. They also compared the causative pathogens among the patients who developed SSI. They found that 31 of $51(60.7 \%)$ vancomycin-treated SSI patients were positive for gram-negative pathogens, while only 12 of 57 historic controls with an SSI were found to be positive for gram-negative pathogens. ${ }^{11}$ This study showed that of the patients who developed SSI, there was a relative increase in the percentage of infection caused by gram-negative pathogens in the vancomycin-treated group.

A study by Adogwa et al. was also excluded from analysis due to a lack of a control group. However, the study demonstrated that over half of the patients treated with vancomycin powder who developed SSI were positive for gram-negative pathogens. ${ }^{2}$

In a study of 5909 cases of posterior thoracic or lumbar surgeries, Grabel et al. found 115 cases of SSI. ${ }^{12}$ After a review of the 115 cases of SSI, they found that 42 patients received vancomycin powder while 73 did not. Within the vancomycin treatment group, 7 patients $(16.7 \%)$ developed SSI due to gram-negative pathogens, while 3 patients (4.1\%) 
TABLE 1. Rates of infection by any pathogen

\begin{tabular}{|c|c|c|c|c|c|c|}
\hline Authors \& Year & $\begin{array}{l}\text { Type of } \\
\text { Study }\end{array}$ & Quality of Study* & $\begin{array}{c}\text { Dosage of } \\
\text { Vancomycin (g) }\end{array}$ & $\begin{array}{l}\text { Rate of Infection } \\
\text { in Control Group }\end{array}$ & $\begin{array}{l}\text { Rate of Infection } \\
\text { in Tx Group }\end{array}$ & $\begin{array}{c}\mathrm{RR} \\
(95 \% \mathrm{Cl})\end{array}$ \\
\hline Sweet et al., 2011 & $\begin{array}{l}\text { Retro } \\
\quad \text { cohort }\end{array}$ & $\begin{array}{l}\text { Selection: } 4 / 4 \text {; comparability: } 0 / 2 \text {; } \\
\text { outcome: } 2 / 3\end{array}$ & 2 & $21 / 821(2.6 \%)$ & $2 / 911(0.2 \%)$ & $0.09(0.02-0.36)$ \\
\hline O’Neill et al., 2011 & $\begin{array}{l}\text { Retro } \\
\text { cohort }\end{array}$ & $\begin{array}{l}\text { Selection: } 4 / 4 \text {; comparability: } 0 / 2 \text {; } \\
\text { outcome: } 2 / 3\end{array}$ & 1 & $7 / 54(13 \%)$ & $0 / 56(0 \%)$ & $0.06(0.00-1.10)$ \\
\hline Caroom et al., 2013 & $\begin{array}{l}\text { Retro } \\
\text { cohort }\end{array}$ & $\begin{array}{l}\text { Selection: } 4 / 4 \text {; comparability: } 0 / 2 \text {; } \\
\text { outcome: } 2 / 3\end{array}$ & 1 & $11 / 72(15 \%)$ & $0 / 40(0 \%)$ & $0.08(0.00-1.28)$ \\
\hline Pahys et al., 2013 & $\begin{array}{l}\text { Retro } \\
\text { cohort }\end{array}$ & $\begin{array}{l}\text { Selection: } 4 / 4 \text {; comparability: } 0 / 2 \text {; } \\
\text { outcome: } 2 / 3\end{array}$ & 0.5 & $9 / 483(1.9 \%)$ & $0 / 195(0 \%)$ & $0.13(0.00-2.22)$ \\
\hline Strom et al., $2013^{31}$ & $\begin{array}{l}\text { Retro } \\
\text { cohort }\end{array}$ & $\begin{array}{l}\text { Selection: } 4 / 4 \text {; comparability: } 0 / 2 \text {; } \\
\text { outcome: } 3 / 3\end{array}$ & 1 & $10 / 92(10.9 \%)$ & $2 / 79(2.5 \%)$ & $0.23(0.05-1.03)$ \\
\hline Strom et al., $2013^{32}$ & $\begin{array}{l}\text { Retro } \\
\text { cohort }\end{array}$ & $\begin{array}{l}\text { Selection: } 4 / 4 \text {; comparability: } 1 / 2 \text {; } \\
\text { outcome: } 3 / 3\end{array}$ & 1 & $11 / 97(11.3 \%)$ & $0 / 156(0 \%)$ & $0.03(0.00-0.46)$ \\
\hline Tubaki et al., 2013 & $\mathrm{RCT}$ & Jadad: $3 / 5$ & 1 & $8 / 474(1.7 \%)$ & $7 / 433(1.6 \%)$ & $0.89(0.33-2.45)$ \\
\hline Heller et al., 2015 & $\begin{array}{l}\text { Retro } \\
\text { cohort }\end{array}$ & $\begin{array}{l}\text { Selection: } 4 / 4 \text {; comparability: } 0 / 2 \text {; } \\
\text { outcome: } 2 / 3\end{array}$ & $0.5-2.0$ & $18 / 341(5.3 \%)$ & $9 / 342(2.6 \%)$ & $0.50(0.23-1.09)$ \\
\hline Hill et al., 2014 & $\begin{array}{l}\text { Retro } \\
\text { cohort }\end{array}$ & $\begin{array}{l}\text { Selection: } 4 / 4 \text {; comparability: } 0 / 2 \text {; } \\
\quad \text { outcome: } 2 / 3\end{array}$ & $1-2$ & $11 / 150(7.3 \%)$ & $5 / 150(3.3 \%)$ & $0.46(0.16-1.28)$ \\
\hline Martin et al., 2014 & $\begin{array}{l}\text { Retro } \\
\text { cohort }\end{array}$ & $\begin{array}{l}\text { Selection: } 4 / 4 ; \text { comparability: } 0 / 2 \text {; } \\
\text { outcome: } 1 / 3\end{array}$ & 2 & $8 / 150(5.3 \%)$ & $8 / 156(5.1 \%)$ & $0.96(0.37-2.50)$ \\
\hline Schroeder et al., 2016 & $\begin{array}{l}\text { Retro } \\
\text { cohort }\end{array}$ & $\begin{array}{l}\text { Selection: } 4 / 4 \text {; comparability: } 0 / 2 \text {; } \\
\text { outcome: } 1 / 3\end{array}$ & $1-1.5$ & $30 / 2253(1.3 \%)$ & $5 / 1224(0.4 \%)$ & $0.31(0.11-0.79)$ \\
\hline Mirzashahi et al., 2018 & $\mathrm{RCT}$ & Jadad: $3 / 5$ & $1-2$ & $15 / 187(8.0 \%)$ & $10 / 193(5.2 \%)$ & $0.65(0.30-1.40)$ \\
\hline Horii et al., 2018 & $\begin{array}{l}\text { Retro } \\
\text { cohort }\end{array}$ & $\begin{array}{l}\text { Selection: } 4 / 4 \text {; comparability: } 0 / 2 \text {; } \\
\text { outcome: } 1 / 3\end{array}$ & $1-2$ & $21 / 2165(1.0 \%)$ & $12 / 694(1.7 \%)$ & $1.78(0.88-3.60)$ \\
\hline Hida et al., 2017 & $\begin{array}{l}\text { Retro } \\
\quad \text { cohort }\end{array}$ & $\begin{array}{l}\text { Selection: } 4 / 4 \text {; comparability: } 0 / 2 \text {; } \\
\text { outcome: } 2 / 3\end{array}$ & $0.5-1$ & $4 / 93(4.3 \%)$ & $0 / 81(0 \%)$ & $0.13(0.01-2.33)$ \\
\hline Chotai et al., 2017 & $\begin{array}{r}\text { Prospect } \\
\text { cohort }\end{array}$ & $\begin{array}{l}\text { Selection: } 4 / 4 \text {; comparability: } 0 / 2 \text {; } \\
\text { outcome: } 2 / 3\end{array}$ & 1 & $40 / 1587(2.5 \%)$ & $20 / 1215(1.6 \%)$ & $0.65(0.38-1.11)$ \\
\hline Tomov et al., 2015 & $\begin{array}{l}\text { Retro } \\
\text { cohort }\end{array}$ & $\begin{array}{l}\text { Selection: } 4 / 4 \text {; comparability: } 0 / 2 \text {; } \\
\text { outcome: } 1 / 3\end{array}$ & 1 & $30 / 1252(2.4 \%)$ & $15 / 1173(1.3 \%)$ & $0.53(0.29-0.99)$ \\
\hline Van Hal et al., 2017 & $\begin{array}{l}\text { Retro } \\
\text { cohort }\end{array}$ & $\begin{array}{l}\text { Selection: } 4 / 4 \text {; comparability: } 0 / 2 \text {; } \\
\text { outcome: } 1 / 3\end{array}$ & 1 & $37 / 652(5.7 \%)$ & $16 / 496(3.2 \%)$ & $0.57(0.32-1.01)$ \\
\hline $\begin{array}{l}\text { Van Herwijnen et al., } \\
2016\end{array}$ & $\begin{array}{l}\text { Retro } \\
\text { cohort }\end{array}$ & $\begin{array}{l}\text { Selection: } 4 / 4 \text {; comparability: } 0 / 2 \text {; } \\
\text { outcome: } 2 / 3\end{array}$ & 1 & $4 / 15(26.7 \%)$ & $2 / 32(6.3 \%)$ & $0.23(0.05-1.14)$ \\
\hline Garg et al., 2018 & $\begin{array}{l}\text { Retro } \\
\text { cohort }\end{array}$ & $\begin{array}{l}\text { Selection: } 4 / 4 \text {; comparability: } 1 / 2 \text {; } \\
\text { outcome: } 2 / 3\end{array}$ & $0.5-2$ & $6 / 310(1.9 \%)$ & $7 / 228(3.1 \%)$ & $1.59(0.54-4.66)$ \\
\hline Thompson et al., 2018 & $\begin{array}{l}\text { Retro } \\
\text { cohort }\end{array}$ & $\begin{array}{l}\text { Selection: } 4 / 4 \text {; comparability: } 0 / 2 \text {; } \\
\text { outcome: } 1 / 3\end{array}$ & $1-1.5$ & $12 / 87(13.8 \%)$ & $5 / 104(4.8 \%)$ & $0.35(0.13-0.95)$ \\
\hline Hey et al., 2017 & $\begin{array}{l}\text { Retro } \\
\text { cohort }\end{array}$ & $\begin{array}{l}\text { Selection: } 4 / 4 ; \text { comparability: } 1 / 2 \text {; } \\
\text { outcome: } 1 / 3\end{array}$ & 1 & $17 / 272(6.3 \%)$ & $1 / 117(0.9 \%)$ & $0.14(0.02-1.02)$ \\
\hline Total & & & & $330 / 11,607(2.8 \%)$ & $126 / 8075(1.6 \%)$ & $0.55(0.45-0.67)$ \\
\hline
\end{tabular}

Prospect $=$ prospective; $\mathrm{RCT}=$ randomized controlled trial; Retro = retrospective; $\mathrm{Tx}=$ treatment.

${ }^{*}$ Retrospective and prospective cohort studies were scored according to the NOS.

in the untreated group developed SSI due to gram-negative pathogen. This study was excluded from the overall analysis, as the authors did not specify the number of patients who received intraoperative vancomycin powder.

\section{Dosing Regimen}

While intrawound vancomycin powder was found to significantly reduce the risk of SSI, optimal dosing regimens have yet to be determined. The doses administered in the included studies ranged from $0.5 \mathrm{~g}$ to $2 \mathrm{~g}$. There is some evidence to suggest that the dose of vancomycin can influence which pathogen causes infection. Xie et al. found that a dose of $1 \mathrm{~g}$ of vancomycin powder was more likely to result in infection due to a gram-negative pathogen, while a dose of $2 \mathrm{~g}$ was more likely to result in infection caused by a gram-positive pathogen. ${ }^{42}$ While the reason for this dose-dependent difference is unclear, the authors speculated that it might be attributed to the pharmacological char- 


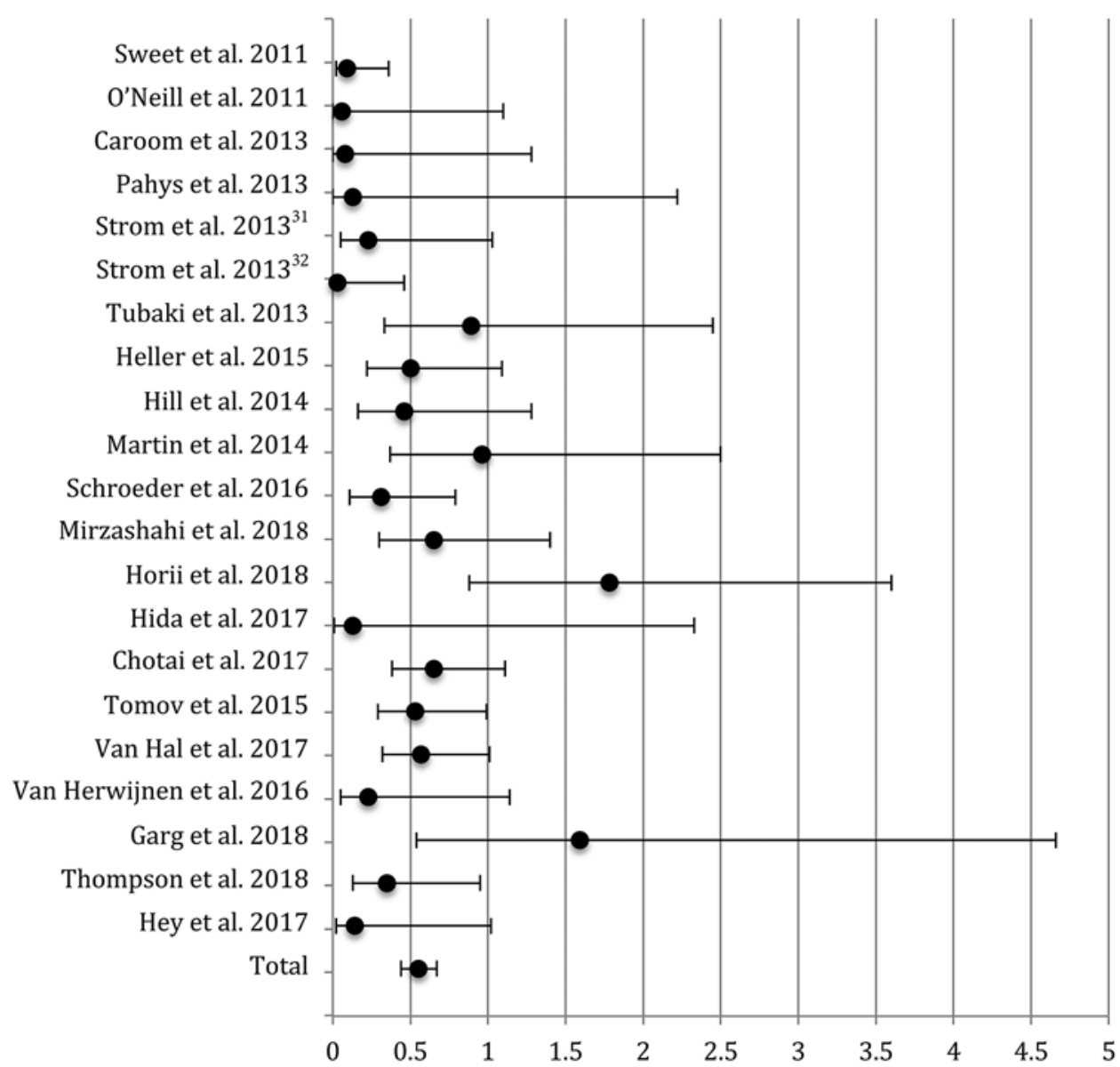

FIG. 2. Forest plot of studies in Table 1. Black dots represent the relative risks. 95\% confidence intervals are given in both directions. The bar at the bottom of the forest plot represents all the data accumulated from every reviewed study.

acteristics of vancomycin. Too high a dose of intrawound vancomycin powder may inhibit bone remodeling. Eder et al. found that administration of greater than $3 \mathrm{mg} / \mathrm{cm}^{2}$ significantly reduces osteoblast cell proliferation. ${ }^{9}$

\section{Limitations}

While the results of this review suggest that intrawound vancomycin powder is protective against the risk of SSI, there are some limitations that qualify this conclusion. Control groups widely differed between studies. The antibiotic used in the control group varied between studies, as did the use of intrawound irrigation. In addition, while most of the studies defined deep SSI using the Centers for Disease Control and Prevention criteria, some studies did not specify whether the reported SSIs were superficial or deep. Furthermore, this review does not delineate the rate

TABLE 2. Rates of infection by gram-negative pathogen

\begin{tabular}{lcccc}
\hline \multicolumn{1}{c}{ Authors \& Year } & Dosage of Vancomycin (g) & Rate of Infection in Control Group & Rate of Infection in Tx Group & RR (95\% Cl) \\
\hline Horii et al., 2018 & $1-2$ & $4 / 2165(0.2 \%)$ & $4 / 694(0.6 \%)$ & $3.11(0.78-12.44)$ \\
\hline Schroeder et al., 2016 & $1-1.5$ & $4 / 2253(0.2 \%)$ & $1 / 1224(0.1 \%)$ & $0.46(0.05-4.11)$ \\
\hline Strom et al., 2013 31 & 1 & $2 / 92(2.2 \%)$ & $1 / 79(1.3 \%)$ & $0.58(0.05-6.30)$ \\
\hline Strom et al., 2013 32 & 1 & $3 / 97(3.1 \%)$ & $0 / 156(0 \%)$ & $0.09(0.00-1.71)$ \\
\hline Martin et al., 2014 & 2 & $4 / 150(2.7 \%)$ & $4 / 156(2.6 \%)$ & $0.96(0.24-3.78)$ \\
\hline Hida et al., 2017 & $0.5-1$ & $1 / 93(1.1 \%)$ & $0 / 81(0 \%)$ & $0.38(0.02-9.25)$ \\
\hline Chotai et al., 2017 & 1 & $5 / 1587(0.3 \%)$ & $7 / 1215(0.6 \%)$ & $1.83(0.58-5.75)$ \\
\hline Tomov et al., 2015 & 1 & $2 / 1252(0.2 \%)$ & $4 / 1173(0.3 \%)$ & $2.13(0.39-11.63)$ \\
\hline Garg et al., 2018 & $0.5-2$ & $0 / 310(0 \%)$ & $2 / 228(0.9 \%)$ & $6.79(0.33-140.77)$ \\
\hline Hey et al., 2017 & 1 & $10 / 272(3.7 \%)$ & $1 / 117(0.9 \%)$ & $0.23(0.03-1.80)$ \\
\hline Total & & $35 / 8271(0.42 \%)$ & $24 / 5123(0.47 \%)$ & $1.11(0.66-1.86)$ \\
\hline
\end{tabular}




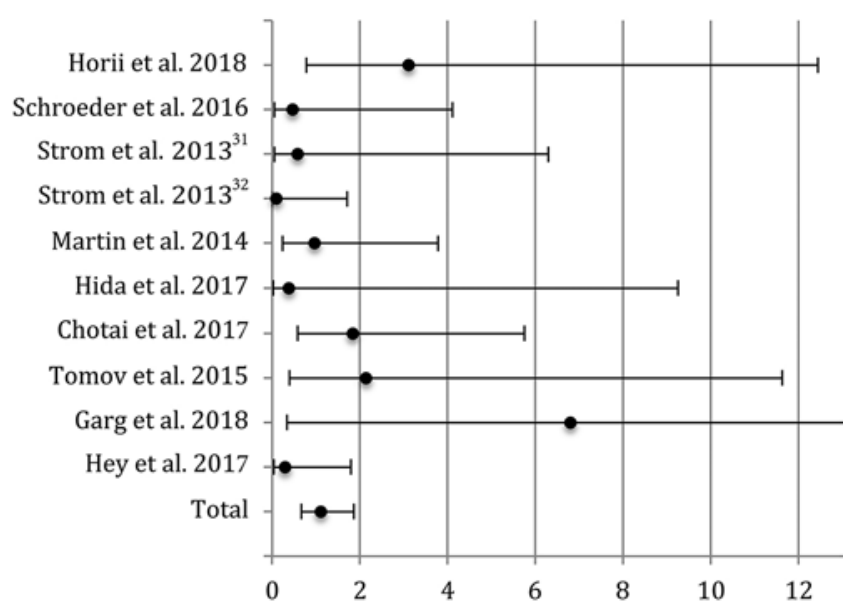

FIG. 3. Forest plot of studies in Table 2. Black dots represent the relative risks. 95\% confidence intervals are given in both directions The bar at the bottom of the forest plot represents all the data accumulated from every reviewed study. The positive error bar for Garg et al. extends to 134 and is not fully shown for formatting consideration.

of infection by type of surgical procedure or whether instrumentation was used. Strom et al. did stratify their findings by instrumentation use and found that regardless of instrumentation, the rate of infection in the controls was similar between instrumentation and noninstrumentation, and vancomycin significantly reduced the rate of infection. ${ }^{32}$ On the other hand, Tubaki et al. found that the rate of infection was higher in the instrumented cases, but vancomycin did not significantly reduce the rate of infection. ${ }^{37}$ Several studies did not specify the time between surgery and infection. Furthermore, many of the studies did not include all patient comorbidities, which might skew the data, as there are several known comorbidities that may predispose patients to infection.

\section{Conclusions}

SSIs after spinal surgeries remain a considerable risk. It is important to determine which patients are at higher risk of SSIs and may benefit from the use of intraoperative vancomycin powder. In addition, the rates of infection due to gram-negative pathogens must be clearly defined in a well-studied manner. The intraoperative use of the direct application of vancomycin powder clearly seems to reduce the risk of SSIs. While some studies have indicated that it is possible for vancomycin to select for gram-negative pathogens, the risk of infection by a gram-negative pathogen needs to be studied further.

\section{References}

1. Abe R, Oda S, Sadahiro T, Nakamura M, Hirayama Y, Tateishi Y, et al: Gram-negative bacteremia induces greater magnitude of inflammatory response than Gram-positive bacteremia. Crit Care 14:R27, 2010

2. Adogwa O, Elsamadicy AA, Sergesketter A, Vuong VD, Mehta AI, Vasquez RA, et al: Prophylactic use of intraoperative vancomycin powder and postoperative infection: an analysis of microbiological patterns in 1200 consecutive surgical cases. J Neurosurg Spine 27:328-334, 2017
3. Beveridge TJ: Structures of gram-negative cell walls and their derived membrane vesicles. J Bacteriol 181:4725-4733, 1999

4. Cannon JGD, Ho AL, Mohole J, Pendharkar AV, Sussman ES, Cheshier SH, et al: Topical vancomycin for surgical prophylaxis in non-instrumented pediatric spinal surgeries. Childs Nerv Syst [epub ahead of print], 2018

5. Caroom C, Tullar JM, Benton EG Jr, Jones JR, Chaput CD: Intrawound vancomycin powder reduces surgical site infections in posterior cervical fusion. Spine (Phila Pa 1976) 38:1183-1187, 2013

6. Chotai S, Wright PW, Hale AT, Jones WA, McGirt MJ, Patt $\mathrm{JC}$, et al: Does intrawound vancomycin application during spine surgery create vancomycin-resistant organism? Neurosurgery 80:746-753, 2017

7. Collins I, Wilson-MacDonald J, Chami G, Burgoyne W, Vinayakam $P$, Berendt $T$, et al: The diagnosis and management of infection following instrumented spinal fusion. Eur Spine J 17:445-450, 2008

8. de Lissovoy G, Fraeman K, Hutchins V, Murphy D, Song D, Vaughn BB: Surgical site infection: incidence and impact on hospital utilization and treatment costs. Am J Infect Control 37:387-397, 2009

9. Eder C, Schenk S, Trifinopoulos J, Külekci B, Kienzl M, Schildböck S, et al: Does intrawound application of vancomycin influence bone healing in spinal surgery? Eur Spine J 25:1021-1028, 2016

10. Garg S, Bloch N, Potter M, Quick H, Palmer C, Michael N, et al: Topical vancomycin in pediatric spine surgery does not reduce surgical site infection: a retrospective cohort study. Spine Deform 6:523-528, 2018

11. Ghobrial GM, Thakkar V, Andrews E, Lang M, Chitale A, Oppenlander ME, et al: Intraoperative vancomycin use in spinal surgery: single institution experience and microbial trends. Spine (Phila Pa 1976) 39:550-555, 2014

12. Grabel ZJ, Boden A, Segal DN, Boden S, Milby AH, Heller JG: The impact of prophylactic intraoperative vancomycin powder on microbial profile, antibiotic regimen, length of stay, and reoperation rate in elective spine surgery. Spine J [epub ahead of print], 2018

13. Hedequist D, Haugen A, Hresko T, Emans J: Failure of attempted implant retention in spinal deformity delayed surgical site infections. Spine (Phila Pa 1976) 34:60-64, 2009

14. Heller A, McIff TE, Lai SM, Burton DC: Intrawound vancomycin powder decreases staphylococcal surgical site infections following posterior instrumented spinal arthrodesis. J Spinal Disord Tech 28:E584-E589, 2015

15. Hey HW, Thiam DW, Koh ZS, Thambiah JS, Kumar N, Lau LL, et al: Is intraoperative local vancomycin powder the answer to surgical site infections in spine surgery? Spine (Phila Pa 1976) 42:267-274, 2017

16. Hida T, Ando K, Kobayashi K, Ito K, Tsushima M, Matsumoto A, et al: Intrawound vancomycin powder as the prophylaxis of surgical site infection after invasive spine surgery with a high risk of infection. Nagoya J Med Sci 79:545-550, 2017

17. Hidron AI, Edwards JR, Patel J, Horan TC, Sievert DM, Pollock DA, et al: NHSN annual update: antimicrobial-resistant pathogens associated with healthcare-associated infections: annual summary of data reported to the National Healthcare Safety Network at the Centers for Disease Control and Prevention, 2006-2007. Infect Control Hosp Epidemiol 29:996-1011, 2008

18. Hill BW, Emohare O, Song B, Davis R, Kang MM: The use of vancomycin powder reduces surgical reoperation in posterior instrumented and noninstrumented spinal surgery. Acta Neurochir (Wien) 156:749-754, 2014

19. Horii C, Yamazaki T, Oka H, Azuma S, Ogihara S, Okazaki $\mathrm{R}$, et al: Does intrawound vancomycin powder reduce surgi- 
cal site infection after posterior instrumented spinal surgery? A propensity score-matched analysis. Spine $\mathbf{J}$ [epub ahead of print], 2018

20. Jadad AR, Moore RA, Carroll D, Jenkinson C, Reynolds DJ, Gavaghan DJ, et al: Assessing the quality of reports of randomized clinical trials: is blinding necessary? Control Clin Trials 17:1-12, 1996

21. Kirkland KB, Briggs JP, Trivette SL, Wilkinson WE, Sexton DJ: The impact of surgical-site infections in the 1990s: attributable mortality, excess length of hospitalization, and extra costs. Infect Control Hosp Epidemiol 20:725-730, 1999

22. Lopez W, Rider SM, Nwosu K, Kazarian E, Blucher J, Schoenfeld E, et al: The impact of vancomycin and cefazolin as standard pre-operative antibiotic prophylaxis on surgical site infections following instrumented spinal fusion. Spine (Phila Pa 1976) [epub ahead of print], 2018

23. Martin JR, Adogwa O, Brown CR, Bagley CA, Richardson WJ, Lad SP, et al: Experience with intrawound vancomycin powder for spinal deformity surgery. Spine (Phila Pa 1976) 39:177-184, 2014

24. Mirzashahi B, Chehrassan M, Mortazavi SMJ: Intrawound application of vancomycin changes the responsible germ in elective spine surgery without significant effect on the rate of infection: a randomized prospective study. Musculoskelet Surg 102:35-39, 2018

25. O'Neill KR, Smith JG, Abtahi AM, Archer KR, Spengler $\mathrm{DM}, \mathrm{McGirt} \mathrm{MJ}$, et al: Reduced surgical site infections in patients undergoing posterior spinal stabilization of traumatic injuries using vancomycin powder. Spine J 11:641-646, 2011

26. Pahys JM, Pahys JR, Cho SK, Kang MM, Zebala LP, Hawasli $\mathrm{AH}$, et al: Methods to decrease postoperative infections following posterior cervical spine surgery. J Bone Joint Surg Am 95:549-554, 2013

27. Park HY, Sheppard W, Smith R, Xiao J, Gatto J, Bowen R, et al: The combined administration of vancomycin IV, standard prophylactic antibiotics, and vancomycin powder in spinal instrumentation surgery: does the routine use affect infection rates and bacterial resistance? J Spine Surg 4:173-179, 2018

28. Rechtine GR, Bono PL, Cahill D, Bolesta MJ, Chrin AM: Postoperative wound infection after instrumentation of thoracic and lumbar fractures. J Orthop Trauma 15:566-569, 2001

29. Schimmel JJP, Horsting PP, de Kleuver M, Wonders G, van Limbeek J: Risk factors for deep surgical site infections after spinal fusion. Eur Spine J 19:1711-1719, 2010

30. Schroeder JE, Girardi FP, Sandhu H, Weinstein J, Cammisa FP, Sama A: The use of local vancomycin powder in degenerative spine surgery. Eur Spine J 25:1029-1033, 2016

31. Strom RG, Pacione D, Kalhorn SP, Frempong-Boadu AK: Decreased risk of wound infection after posterior cervical fusion with routine local application of vancomycin powder. Spine (Phila Pa 1976) 38:991-994, 2013

32. Strom RG, Pacione D, Kalhorn SP, Frempong-Boadu AK: Lumbar laminectomy and fusion with routine local application of vancomycin powder: decreased infection rate in instrumented and non-instrumented cases. Clin Neurol Neurosurg 115:1766-1769, 2013

33. Suh BK, Moon SH, Kim TH, Oh JK, Kwon YS, Park JS, et al: Efficacy of antibiotics sprayed into surgical site for prevention of the contamination in the spinal surgery. Asian Spine J 9:517-521, 2015

34. Sweet FA, Roh M, Sliva C: Intrawound application of vancomycin for prophylaxis in instrumented thoracolumbar fusions: efficacy, drug levels, and patient outcomes. Spine (Phila Pa 1976) 36:2084-2088, 2011

35. Thompson GH, Poe-Kochert C, Hardesty CK, Son-Hing J, Mistovich RJ: Does vancomycin powder decrease surgical site infections in growing spine surgery?: A preliminary study. J Bone Joint Surg Am 100:466-471, 2018

36. Tomov M, Mitsunaga L, Durbin-Johnson B, Nallur D, Roberto R: Reducing surgical site infection in spinal surgery with betadine irrigation and intrawound vancomycin powder. Spine (Phila Pa 1976) 40:491-499, 2015

37. Tubaki VR, Rajasekaran S, Shetty AP: Effects of using intravenous antibiotic only versus local intrawound vancomycin antibiotic powder application in addition to intravenous antibiotics on postoperative infection in spine surgery in 907 patients. Spine (Phila Pa 1976) 38:2149-2155, 2013

38. Van Hal M, Lee J, Laudermilch D, Nwasike C, Kang J: Vancomycin powder regimen for prevention of surgical site infection in complex spine surgeries. Clin Spine Surg 30:E1062E1065, 2017

39. van Herwijnen B, Evans NR, Dare CJ, Davies EM: An intraoperative irrigation regimen to reduce the surgical site infection rate following adolescent idiopathic scoliosis surgery. Ann R Coll Surg Engl 98:320-323, 2016

40. Watanabe M, Sakai D, Matsuyama D, Yamamoto Y, Sato M, Mochida J: Risk factors for surgical site infection following spine surgery: efficacy of intraoperative saline irrigation. J Neurosurg Spine 12:540-546, 2010

41. Wells GA, Shea B, O’Connell D, Peterson J, Welch V, Losos M, Tugwell P: The Newcastle-Ottawa Scale (NOS) for assessing the quality of nonrandomized studies in meta-analyses. Ottawa Hospital Research Institute. (http://www.ohri. ca/programs/clinical_epidemiology/oxford.asp) [Accessed November 29, 2018]

42. Xie L, Zhu J, Luo S, Xie Y, Pu D: Do dose-dependent microbial changes occur during spine surgery as a result of applying intrawound vancomycin powder?: a systematic literature review. Asian Spine J 12:162-170, 2018

43. Yamada K, Abe H, Higashikawa A, Tonosu J, Kuniya T, Nakajima K, et al: Evidence-based care bundles for preventing surgical site infections in spinal instrumentation surgery. Spine (Phila Pa 1976) [epub ahead of print], 2018

\section{Disclosures}

The authors report no conflict of interest concerning the materials or methods used in this study or the findings specified in this paper.

\section{Author Contributions}

Conception and design: Assina, Majmundar. Acquisition of data: Dodson, Majmundar, Swantic. Analysis and interpretation of data: Assina, Dodson, Majmundar. Drafting the article: all authors. Critically revising the article: Assina, Majmundar. Reviewed submitted version of manuscript: all authors. Approved the final version of the manuscript on behalf of all authors: Assina. Statistical analysis: Dodson. Administrative/technical/material support: Assina. Study supervision: Assina.

\section{Correspondence}

Rachid Assina: Rutgers New Jersey Medical School, Newark, NJ. assinara@njms.rutgers.edu. 